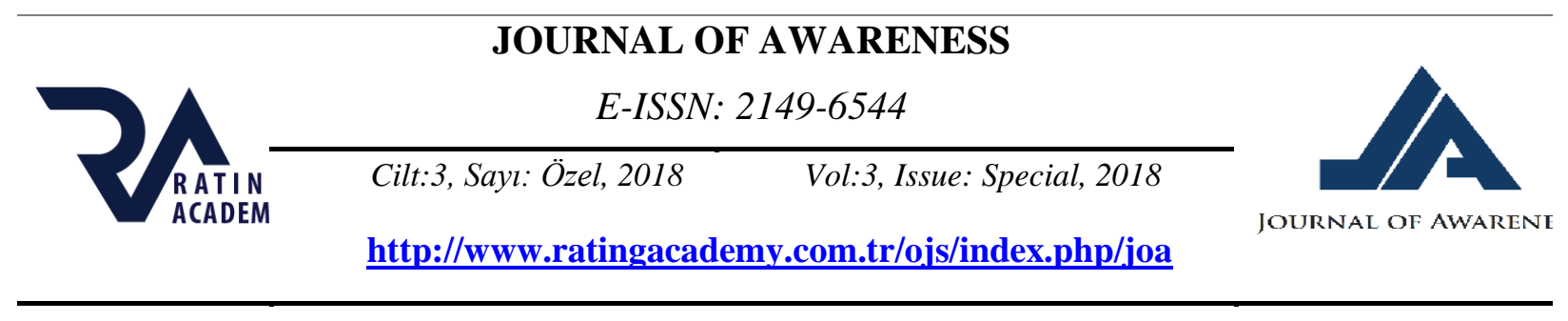

\title{
THE POETIC STRUCTURE OF LEXICAL UNITS OF AZERBAIJAN BAYATIES*
}

\author{
Gulqiz Hajibala MIRZOYEVA (ADILOVA) \\ Teacher of The Chair of Azerbaijan Language and Its Teaching Methodology at \\ Baku Slavic University \\ E-mail: gulagh2@gmail.com
}

\begin{tabular}{l|l}
\hline ARTICLE INFO & \multicolumn{1}{c}{ ABSTRACT } \\
\hline $\begin{array}{l}\text { Keywords: } \\
\text { Bayaty, stylistic shades, } \\
\text { lexis, poetic language, } \\
\text { poetic thinking. }\end{array}$ & $\begin{array}{l}\text { Bayaties are poetic language examples reflecting the richness of vocabulary, the } \\
\text { colourfulness of mother tongue `s expression capabilities, the fluency of the sound } \\
\text { structure and the stability of the grammatic structure. The main purpose of the } \\
\text { article is investigating the poetechnical level of the oral literary language in the } \\
\text { evolutionary stages of the popular language, the role of the folklore style on the } \\
\text { lexic layer of the language, the richness of the expression possibilities basing on } \\
\text { the factual linguistic materials. }\end{array}$ \\
\hline $\begin{array}{l}\text { DOI: } \\
10.26809 / j o a .2018548652\end{array}$ & \\
\hline
\end{tabular}

\section{INTRODUCTION}

One of the samples of our folk literature - bayaties tell us about the formation of the oral speech, artistic thinking style of our people many centuries ago and their gradual development and enrichment over time. The ability to compose from one to eight sentences in a small poetic piece consisting of four hemistiches of twenty eight syllables, to create all kinds of simple sentences, even bigger syntactic units - complex sentences, micro and macro texts for achieving absolute expression of an idea of a people unaware of the grammatical structure of the language is a great discovery in terms of the linguistics. All of these facts prove that the people had founded their "national linguistic science" even some centuries ago. From this point of view, bayaties are perfect poetic linguistic example reflecting the purity of the popular language, the development way that it passed since it had detached from a great Turkish language family.

As the researchers noted, "The historically ancient bayaty genre has not been adequately commented on and explained in terms of language and style features yet. However, bayaties whose author is the Azerbaijani people can give a very reach material by explaining a number of grammatical, lexical, stylistic and other features concerning real popular language"(2.51).

The sample of oral literature - bayaty attracts attention by its poetic perfection reflecting specific features of phonetic, lexical and grammatical norms of poetic Azerbaijani language and the nicety of the popular language. That is why, involvement of bayaties in the investigation is one of the urgent issues of modern linguistics from linguistic - poetic point of view.

The language of bayaties is the language expressing the reality by the people as they understand it. It is known that the first source of human aesthetic feelings is the marvellous, 
mysterious beauty of the nature where they live in. Meantime, songs, bayaties, folk music and other lyrical fragments suggesting the feeling of beauty and describing the nature figuratively are composed.

As we know, while trying to identify the aesthetic value of any language unit, its phonetic, lexical, and morphological and syntactic signs should be regarded as a single system. Because, the language and speech units are directly compatible with the language layers. "Each language unit is based on a unit standing below itself and differs from the unit above by its function" (6 p. 6). Therefore, in the study of the word, the general system of language is taken as a basis and it consists mainly of four elements - sound and meaning, word and morphism, word combinations and sentences.

Thus, studies have proven that poetry is manifested in all levels of language. It stipulates the structure of phonetic, lexical, and morphological elements.

The term poetics has been used throughout the history as the term concerning the language and structure of poetry and prose works and the name of the science named literature since the ancient times. Unlike other philosophers in the "imitation" theory spoken about in the work "Poetry", the greatest poetical theorist of the ancient world Aristotle does not link art and its origin to supernatural ideas. "Aristotle's" imitation-mimesis "theory is of a secular character, it encompasses the creative and artistic refinement of reality and recognizes and perceives the cognitive and educational role of art" (3.p.8).

Thus, it is understood from the theoretical ideas that artistic creativity originates from some kind of imitation of life. This imitation is not a simple imitation, but an artistic imitation. It is the figurative, artistic reflection of life and nature phenomena. This kind of reflection came forward from the wish to increase attention to any information that the people want to bring to attention.

The role of intonation is recognized more distinctly in oral literary language samples having high emotionality, including bayaties. In bayaties, perhaps, as we read the most commonly used hemistiches, the inner dynamics in them make us astonished. "Just therefore, our scientists are faced with a very sacred and postponing task such as finding and studying the precious parts of this cultural treasure which have not been found or deeply studied yet" (5. p.6).

It proves that bayaties are not valuable just as folk example of oral literature, but as the poetic expression of the people's attitude to reality, feelings of joy, sadness and senses. Bayaties reflect the grammatical structure, artistic world, centuries-old history, geography, flora, fauna of the natural language of the people.

$$
\begin{aligned}
& \text { Apardı Batı məni, } \\
& \text { Qul edib satı məni, } \\
& \text { Yollar uzun, mən yorğun, } \\
& \text { Doğrayır çatı məni (1.p.7). } \\
& \text { Su gəlir lilləndirir, } \\
& \text { Bağçanı gülləndirir, } \\
& \text { Mənə dərdsiz deyirlər, } \\
& \text { Dərd məni dilləndirir (9. p. 304). }
\end{aligned}
$$

Reflecting their many-centuries history, life mood, emotional sadness, psychological state, joy with the figurative expressions in the given smaller lyrical pieces, the people demonstrate clearly simultaneous development of science and artistic thinking in the dynamism 
in the rhymes within the hemistiches and in the harmony of the rhythm and thus, it reveals poetic meaning of a word.

Aristotle emphasizes the role of rhythm, speech and harmony in his work "Poetry": "As imitation is inherent to human nature like harmony and rhythm, those who had the same natural abilities have gradually developed it, created poetry from improvisation (real) since the ancient times "(3.p.27).

The German linguist Karl Fossler approaches the language from the aesthetic point of view and calls the aesthetic the science on the expression of spirit and intuition. Thus, Fossler took the expressive function of the language as the basis and tried to explain it from the aesthetic point of view. "Fossler considered that the main function of the natural human language is the expressive function, the language shall be studied just from this point of view" (10.p.327)

Expressiveness for the literary-artistic language is the main characteristic feature. It expresses emotions of the people and is evoked by certain expressive actions. This means that expressiveness does not only serve the linguistic units to be expressive, but also reveals the inner world, mood, and psychological state of those making these units expressive. For example:

\section{Dərdim elə car, haray! \\ Qara günüm var, haray! (8.p. 48). \\ 2. Ağacada xəzəl ağlar, Dibində gözəl ağlar (9.p.238).}

Given bayaties are also distinguished by the fact that they are rich in figurative words and phrases from head to foot. The lyrics distinguished just by the stylistic shades are called poetic words.

The poetic scope of the word is one of the typical features of the literary language. The figurative expression of the idea is coverage by the artistic cloth. In other words, poetic words are directly figurative and fine expression of a complete aesthetic thought.

According to $\mathrm{H}$. Hasanov, "poetic lexism is established basing on folk poetry (dadaş, can, canan), a possibility of new word composition (q1zciğaz) and some words borrowed from other languages (əfsus, təəssüf, səfa, cəfa and so on.)" (6.p. 251).

Expressiveness shows itself at all levels of the language - phonetic, lexical and grammatical levels.

The expression tool of expressiveness is more comprehensive at the lexical level. Because, the lexical units play the most important role in figurative expression of artistic thinking. The colorful poetic meaning and gaining new shades of the same word in the text appears as an artistic discovery in the language.

It is known that, the expressiveness appears as metaphors, polysemantic words, synonyms, antonyms, homonyms, lexical repetitions and so on at the lexical level.

Since the society is the integral part of the nature, natural harmony has been reflected in the human consciousness even from the earliest times. At the initial stages of the creation, myths and legends were composed as the result of interest of primitive people in learning the causes of nature phenomena and their spontaneous attitude to them. Thus, being unaware, natural link - harmony was established between the inner world of people and the nature. Over time, having no idea about writing and reading, the people used these tools skilfully and already composed their "speech books" - their songs, slogans, bayaties, sagas and so on. Thus, poetry and emotionalism appeared naturally in the people's creativity. 


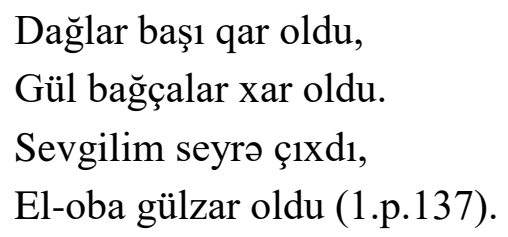

As you can see, bayaty has descriptive feature. There are contradictions between the parts of bayaty. Covering the top of mountains with snow tells about coming of the winter, consequently, disgracing of the heart garden of the lover. But, in the second part, poetic metaphor was created by saying that everywhere became as a flower garden on the eyes of the lover as his beloved woman went out for a walk

The poetic power the oral work treasure - bayaties is related with the rich word world of the people. "Folklore in every nation's own language is the eternal memory of the mother tongue and in reality, every word in the language has such a value determined, stabilized, and changed in the folk language that is the key to opening the essence of the word. The most ancient words, the main roots are derived from folk language. Magic words, poetry, shaman's songs, works and ceremonies being early folklore examples are the basis of oral literature." (7.p. 198).

Indeed, the root of the oral vocabulary of the people is so solid that it has become a solid foundation, an endless source for future written literature. From time to time, poets and writers have created several examples of written literature based on centuries-olds legends, sagas, epics, bayaties survived by being filtered from lip-to-lips, from memories.

The number of syllables, rhythm, intonation, accent in bayaties is characteristic to the people's epic thoughts and thinking style. However, bayaties of which the possibilities of expression are often the sign of philosophical thought are met enough:

1. Dünya, "mənim" deyənin, İndi gəldim yasinnan (9.p. 174).

2. Bu dünya bir pəncərədir, Hər gələn baxar gedər (9.p.152).

In these examples, we witness once again the figurative expression of the primitive philosophical thought of the Azerbaijani people. Here, the ability of the people to express in a simple language such philosophic thoughts like as the world is not a place to stay, nobody is able to withstand against the laws of the nature in both lyric episodes of four hemistiches, notwithstanding that the same idea was expressed in a simple sentence in the first bayaty and in the complicated sentence in the second sentence. However, the simple sentence also contains a compound sentence member. These were grammatical rules created naturally in the oral language of people who were unaware of linguistic science.

One of the ways to create a rhythm in bayaty is the repetition of one or more words in the hemistiches. Of course, these repetitions are not spontaneous.

1. Qoxusu güldən gəlir, Güldən, bülbüldən gəlir (1.p. 103).

2. Qarşı1da inci mənəm, Ləl mənəm, inci mənəm (9.p. 48).

The first parts of the above-stated bayaties were compiled with the set norm. Thus, some of the words used in the first verse are repeated on certain rhythm in the second verse. Such 
repetitions serve not only to the rhyme, but also to make the rhythm and harmony in the verses, which play a certain role in determining the poetic structure of bayaties.

Over time, it is unavoidable that some of the changes in the genre of poetry of the people, especially in the lexical language of the language, can be made. However, these changes do not have a negative impact on poetechnics, poetics, rhythm and rhyme system.

Multivariety is one of the main features of oral literature. However, the variance in bayaties is entailed by its mastery.

Hence, multivariety of oral folk literature not only reduces the artistic-aesthetic value of its genres, especially lyric genres, but even adds a new color and a new shade to it. This is due to the fact that bayaties were not distorted while passing through the history, but rather the expression potential of the idea has been increased.

1. Analar yanar ağlar,

Gününü sanar ağlar.

Donu göy göyərçinlər,

Məzara qonar ağlar (9.p. 85).

2. Anası yanar ağlar,

Dərdini qanar ağlar.

Ana deyib göyərçin,

Tabuta qonar, ağlar ( 8.p. 87).

3. Analar yanar ağlar

Günlərin sanar ağlar.

Dönər göy göyərçinə,

Yollara qonar ağlar (8.p. 85)

It is also known that each version of the given bayaty appeared at different times, and the figurative expression style and emotionality in all three variants vary from each other in some extent. As if the first and the second bayaties are divided into two parts. In the first part the mother lost her baby crying again, counting the days and in the second part, perching of doves in blue cloth on the grave and their crying. There is not any connection in regard to the content between them.

However, both parts have artistic and figurative expression means, but this is not as unusual. Because crying of the mother sore at heart everyday is natural. In the second part, wearing a blue cloth and crying of a dove increases the expressiveness as a metaphor.

The third version of bayaty is more perfect in terms of style and content. There is a general connection between becoming a blue dove and perching on road and crying of the mother who lost her baby and other verses of bayati. As wellç crying of the mother sore at heart not at home or at the grave, but becoming a blue dove and perching on roads increases again the poetic character of bayati.

As it can be seen from the example, the fact that the bayaties composed in the linguistic manifestation of Azerbaijani people are laconic in regard to its volume requires skilful use of the linguistic units

The characteristic of the Azerbaijani people in the language manifestations is so compact that it requires creators to use skillfully the language units from their composers. 
The language of the period when it was composed, its vocabulary and other issues are studied in details in the analysis of any literary- artistic text (both written and oral), as well, poetic structure of lexical units of bayaties. As a result of enough use of the artistic descriptive and expression means, the figurativeness increases, the poetic possibilities of the language become more evident. All of this comes from the ability to express ideas by wearing aesthetic gowns to feelings and thoughts. Thus, it is be stated with certainty that, the bases of bayaty aesthetics depend on the criteria of the words used in the mother tongue when it was created. Use of the phraselogical combinations, metaphors in the people's speaking lexicon appears as an aesthetic event that creates the harmony of the form and content in the expression of the idea.

$$
\begin{aligned}
& \text { Gündə bir kərpic düşür, } \\
& \text { Ömrümün sarayından (9.p. 142). } \\
& \text { Dindirmə qan ağlaram, } \\
& \text { Sinəmdə yar dağı var (1 p. 144). }
\end{aligned}
$$

The phraseological combinations found in bayaties ensure once again the national character of the languages, enhance its artistry and expressiveness. It has a general characteristic for the oral branch of the literary Azerbaijani language.

"The structure of the word" in the linguistics is studied in two aspects. The first one is its grammatical structure. When saying grammatical structure, its syllabic system, composition, and composition are understood and they are studied in the phonetics and the morphology sections of the linguistics.

The second aspect is the meaning structure of the word, which implies various meanings that are combined around one meaning. But, it does not mean that the meaning of the word must be included in the meaning structure of the word. It is evident that there is a difference between the meaning of the word and its initial meaning.

It is well-known that the meaning shade is not imagined without the speech. It is worth mentioning that national lexicon prevails in bayaties.

The poetry of bayaty is related to the word world of its creators. "Language gaining meaning in a word mobilizes the phonetic and syntactic means basing on lexicon." (Encyclopedia K.D.Q., 2001, p. 200).

When talking about the technical structure of bayati, studying the meaning shades of every word, its artistic - aesthetic value and poetic functions is one of the important issues.

When referring to the technical structure of bayaty genre, the folk poetry form consisting of four letters, each of which consists of seven syllables is illustrated and of which the first, second and fourth rhymes are the same and the third rhyme is free. The first two hemistiches are the artistic basis - ground for ideas to be expressed in the next verse.

From the Middle Ages, prominent scholars, folklore lovers engaged in collecting and researching bayaties, have copied out the ancient bayaty samples and were the mediators of survival of their first version in the modern era as well.

Some of the bayaties kept in the form of handwritings in archives, cuffs and bayazes are slightly different from the modern bayaties for their structure and composition. It becomes evident that bayaties don't only consist of four letters and seven syllables. In one verse it is possible to find bayaties with six, seven and eight syllables and six hemistiches. We get acquainted with these bayaties through the bayaties collected from various manuscripts concerning different periods of the great scholars, folklore scientists involved in the study of ancient bayaties. These bayaties are actually considered macro tests and consist of three parts. 
The first two parts are the introductory parts, the third and the fourth parts are the main parts and the last, the fifth and the sixth parts are the result, made judgment.

Bayaty copied out by Saddullah Bardai in the XVIII century:

Әzizi mən də munun,

Nəsi var məndə munun,

Çox cəfalar çəkmişəm,

Yolunda mən də munun.

O connətə çıraxdır,

Kösöy(ü) mən də munun (9.p. 33).

The national character and richness of the language of bayaties is always high as the criterion of the national poetry. We see this in high position of the primitive poetry rhythm syllable as the leading, national rhythm. The structure, rhythm, poetic rhythm of bayaties enhances their artistic-aesthetic essence.

One of the first poetry examples of verbal speech - bayaty activates the linguistic materials stagnant in many centuries. Gaining different meaning shades of words and expressions forgotten in our language and their easy understanding by the people isn't satisfied only by studying the development stages of the language, also informs about the poetic features of the folk artistic thinking.

1. Gözəllik soy iləndir, Şahmar da soy ilandır (8.p. 76).

The word "soy" is used in the mening of a family, root here. Though that it is an archaic word, recently it has become an efficient word again.

2. Sayriyam, sağalmanam,

Heç bilmən, nəmdir mənim (9.p. 15).

"Sayrı" was used as a sick man here and it is still an archaic word.

The words from this family are quite common in bayaties. This proves that "although there is a change in the lexical layer of the folk language," generally, there is a fact that the word is the poetic figurative unit, artistic expression means,... protects the vocabulary of the folk language"(10.p.4). 


\section{BIBLIOGRAPHY}

Abdullayev B. və b. Azərbaycan bayatıları. Bakı, 1984.

Adilov M. Xalq şeirinin ritmi haqqında. Azərbaycan folklorşünaslığı məsələləri. Bakı: ADUnun nəşri, 1983.

Aristotel. Poetika.Bakı,2006.

Dəmirçizadə Ә.Azərbaycan ədəbi dilinin tarixi. Bakı, 1979.

Dəmirçizadə Ә. KDQ dastanların dili. Bakı,1959.

Həsənov H. Azərbaycan dilinin leksikası. Bak1, 2001.

Kitabi-Dədə Qorqud ensilopediyası.II cild. Bak1, 2000.

Qasımov H. Bayatılar. Azərnəşr.1960.

Məmmədova A. Bayatılar. 1977.

Məmmədova Sevil. Bayatıdan dastana. Bak1.2010. 